Marta Walewska

Uniwersytet w Białymstoku

E-MAIL: m.wyszynska@uwb.edu.pl

\title{
Co irytuje twórczych nauczycieli?
}

\section{STRESZCZENIE}

W przypadku zawodu nauczyciela istnieje wiele sytuacji wywołujących irytację tej grupy społecznej. Termin irytacja występuje też w kontekście syndromu wypalenia zawodowego. Temat podjęto $\mathrm{z}$ uwagi na konsekwencje, jakie on wywołuje, zarówno w życiu zawodowym, jak i prywatnym nauczycieli. W artykule przedstawiono wyniki badań jakościowych, które przeprowadzono w kwietniu i maju 2013 roku przez autorkę artykułu w ramach pracy doktorskiej. Uczestniczyły w nich nauczycielki wykazujące preferencje w zakresie twórczych orientacji życiowych - osoby, które zmiany i różnicę traktują jako naturalny porządek rzeczy, chętnie podejmują się realizowania nowych zadań, szukają nowych możliwości i sposobów rozwiązania trudnych sytuacji. W badaniach zastosowano metodę indywidualnych przypadków, techniką był wywiad w postaci kwestionariusza wywiadu. Wykorzystano koncepcję analizy danych jakościowych Mathew B. Milesa i A. Michaela Hubermana. W świetle przeprowadzonych badań irytację twórczych nauczycieli wywoływały takie aspekty szkolnej rzeczywistości, jak: poziom kursów organizowanych w ramach doskonalenia zawodowego, formy przeprowadzania i oceniania sprawdzianów oraz konkursów, biurokracja, przepisy prawa oświatowego, nadmierne oczekiwania rodziców wobec dzieci, jak też wyposażenie szkół. W przypadku jednej osoby wystąpiło zmęczenie pracą i zniechęcenie, które mogło doprowadzić do objawów wypalenia zawodowego. Wyniki analizy wykazały, że badane nauczycielki irytowały te elementy, które utrudniały im realizowanie postulatu wychowania do twórczości.

sŁoWA KLUCzOWE: twórczy nauczyciel, irytacja, wypalenie zawodowe.

\section{Wprowadzenie}

Społeczeństwo przyszłości potrzebuje nowego typu osobowości, jakim jest osobowość twórcza. Obserwuje się zapotrzebowanie na rozwijanie nowych wzorów zachowania, „przejścia od zachowań replikacyjnych do innowacyjnych, od odtwórczości do twórczości” (Schulz, 1990, s. 356), we wszystkich istotnych dziedzinach życia społecznego. Współczesny twórczy nauczyciel - to osoba o twórczej postawie, bez konieczności profesjonalnego tworzenia. Nie wymaga się, by był np. artystą, muzykiem, plastykiem czy też rzeźbiarzem, jednak powinien posiadać takie cechy, jak: otwartość, wrażliwość, ciekawość świata i uczniów. Połączenie jego wiedzy z pomysłowością sprawia, 
że realizuje zajęcia w sposób niekonwencjonalny oraz potrafi trafnie rozpoznawać uzdolnienia wychowanków i kierować ich rozwojem przy współpracy z ekspertami z danej dziedziny (Karwowski, 2010). Twórczy nauczyciel posiada zdolność inspirowania, wyzwalania wyobraźni, fantazji oraz ujawniania nie zawsze uświadamianych emocji. Poprzez swoje postępowanie zachęca innych do tworzenia, poszukiwania i odkrywania zdolności (Gulińska-Grzeluszka, 2010). To także osoba, którą cechuje odwaga poznawcza, niezależność myślenia, krytycyzm oraz samokrytycyzm. Nie zniechęcają jej trudności i przeszkody, z którymi styka się w swoim działaniu. Trafnie rozpoznaje i reguluje własne stany emocjonalne, tak by nie utrudniały one realizowania celów dydaktycznych i wychowawczych (Zaborowski, 1986). Dodatkowo posiada takie cechy, jak: stanowczość, wysoka motywacja, traktowanie pracy jako pasji, wytrwałość, inicjatywa, krytycyzm, wiara we własne możliwości, otwartość, odwaga, potrzeba doskonalenia (Gulińska-Grzeluszka, 2010).

Wyznacznikiem twórczych orientacji życiowych, specyficznych dla danej jednostki, jest przede wszystkim sposób jej funkcjonowania w społeczeństwie, oparty na aktualizowaniu własnego potencjału rozwojowego, kreowaniu siebie i otaczającego świata. Twórcze orientacje życiowe są zawsze konsekwencją świadomego wyboru i przejawiają się w osobistym i zaangażowanym sposobie pełnienia codziennych obowiązków. Jednostki preferujące twórcze orientacje życiowe zmiany i różnicę traktują jako naturalny porządek rzeczy, wyzwalają one w nich energię do podejmowania kolejnych działań. Jednostki wykazujące preferencje w kierunku twórczych orientacji życiowych chętnie podejmują się realizowania nowych zadań, które traktują jako wyzwania, którym chcą sprostać. Wykazują także poczucie sprawstwa i kontroli, natomiast do rozwiązania pojawiających się trudnych sytuacji szukają nowych możliwości i sposobów. Działania na rzecz samorozwoju i wzbogacania własnej osobowości są ważnym elementem tego typu orientacji (Cudowska, 2014). Wszystkie te cechy istotne są w pracy nauczyciela, która jest złożona, wielowątkowa i dynamiczna. Zmieniają się wymagania, jakie przed tą grupą zawodową stawiają rodzice, społeczeństwo i sami uczniowie. Pojawiają się nowe problemy i wyzwania, którym nauczyciele muszą sprostać. Z tego też powodu preferowanie przez nauczycieli twórczego stylu życia i podejścia do pracy pedagogicznej jest niezwykle ważnym aspektem ich pracy oraz może wpływać na efektywność ich działalności edukacyjnej, a także zapobiegać występowaniu syndromu wypalenia zawodowego. Celem artykułu jest poznanie przyczyn, które wywołują irytację nauczycielek wykazujących preferencje w kierunku twórczych orientacji życiowych. 


\section{Irytacja jako przejaw wypalenia zawodowego}

W literaturze przedmiotu termin irytacja rozumiany jest jako "gniewne podniecenie, rozdrażnienie, denerwowanie się" (Dubisz, 2003, s. 1243), jak też „stan psychiczny, w którym człowiek łatwo wpada w złość, wywołany niezadowoleniem z czegoś, przykrą sytuacją lub zmęczeniem" (Żmigrodzki i in., 2016). W przypadku zawodu nauczyciela istnieje wiele sytuacji wywołujących irytację tej grupy społecznej. Wielość stawianych wymagań powoduje nakładanie na nauczycieli coraz większej odpowiedzialności i jednocześnie obwinianie za braki i niedociągnięcia w systemie edukacji. Skutkuje to wzrastającym poziomem stresu, frustracji oraz nadmiernym obciążeniem pracą (Grzegorzewska, 2008; Kwiatkowski, 2008).

Termin irytacja występuje też w kontekście syndromu wypalenia zawodowego. Zjawisko to po raz pierwszy opisał Herbert J. Freudenberg. Charakteryzuje się ono „poczuciem psychicznego i fizycznego wyczerpania, niecierpliwością, nadmierną skłonnością do irytacji, połączoną z cynizmem i poczuciem chronicznego znudzenia, skłonnością do izolowania się i tłumienia emocji" (Znańska-Kozłowska, 2013, s. 106). Pierwszym symptomem wypalenia zawodowego, wyróżnionym przez Christinę Maslach, jest wyczerpanie emocjonalne, będące efektem zmęczenia wynikającego zazwyczaj z dużej liczby kontaktów zawodowych z innymi ludźmi. Oprócz zaburzeń somatycznych i braku satysfakcji z wykonywanej pracy, pojawiają się także negatywne emocje, takie jak zniechęcenie czy też irytacja. Jednostki będące w tej fazie wypalenia zawodowego starają się ograniczać kontakty interpersonalne. Kolejnymi etapami syndromu są depersonalizacja i obniżone poczucie dokonań osobistych, kiedy myśl o pracy wywołuje lęk i przerażenie (Woźniak-Krakowian, 2013). Również B. Brewster (Kirenko i Zubrzycka-Maciąg, 2011) wyróżnia trzy etapy wypalenia zawodowego, przypisując do nich konkretne zmiany psychosomatyczne. W stadium pierwszym, ostrzegawczym, pojawiają się takie symptomy, jak: bóle głowy, bezsenność oraz uczucie irytacji. $\mathrm{Na}$ poziomie drugim przeradza się ono $\mathrm{w}$ wybuchy irytacji, które połączone są z pogardliwym traktowaniem innych oraz obniżeniem poziomu wykonywania zadań. Brak podjęcia odpowiednich działań prowadzi do pojawienia się objawów psychologicznych i psychosomatycznych, które rzutują nie tylko na życie zawodowe, ale także rodzinne.

Wypalenie zawodowe, zgodnie $\mathrm{z}$ teorią egzystencjalną Alayi M. Pines (Kirenko i Zubrzycka-Maciąg, 2011), dotyczy przede wszystkim tych profesji, które wymagają stałych kontaktów z innymi ludźmi. Przedstawiciele tych zawodów posiadają przekonanie o ważności i przydatności swojej pracy, które jednocześnie wpływa na ich poczucie własnej wartości. Jednak w wy- 
niku negatywnych doświadczeń pojawia się u nich poczucie braku skuteczności i przydatności oraz uczucie zawiedzenia, co naraża ich na syndrom wypalenia. Jego wystąpienie jest bardziej prawdopodobne w przypadku osób ambitnych, o silnej motywacji, które same od siebie wiele oczekują.

\section{Założenia metodologiczne badań własnych}

Prezentowane w tekście wyniki badań pochodzą z projektu, który dotyczył zawodu nauczyciela oraz różnych kwestii społecznych widzianych oczami tej grupy społecznej'. Irytacja nie była bezpośrednim przedmiotem badań, jednak uzyskane dane poddane zostały powtórnej analizie, celem poznania przyczyn wywołujących irytację nauczycieli. Problem badawczy sformułowałam w postaci pytania: jakie przyczyny wywołują irytację nauczycielek wykazujących preferencje w zakresie twórczych orientacji życiowych?

Pierwszy etap projektu, który polegał na przeprowadzeniu badań w strategii ilościowej wśród nauczycieli pracujących w białostockich publicznych szkołach podstawowych z dziećmi w młodszym wieku szkolnym, prowadziłam w trzynastu białostockich szkołach podstawowych od marca do czerwca 2010 roku. Objęłam nimi 120 nauczycieli edukacji wczesnoszkolnej i wychowawców świetlicy pracujących w trzynastu placówkach. Jednak ze względu na niepełne uzupełnienie kwestionariuszy, które mogłoby doprowadzić do nierzetelnych wniosków, do dalszej analizy zakwalifikowałam 112 kompletów narzędzi badawczych. W tym etapie zastosowałam metodę sondażu diagnostycznego, a w nim technikę ankiety i skalowania. Jedną z wykorzystanych skal była Skala Preferencji Twórczych Orientacji Życiowych Agaty Cudowskiej (2004). Służyła ona wyselekcjonowaniu nauczycieli do drugiego etapu badań.

Drugi etap projektu polegał na przeprowadzeniu badań w strategii jakościowej wśród nauczycielek, które w pierwszym etapie wykazały wysokie preferencje dla twórczych orientacji życiowych. Zrealizowałam go w kwietniu i maju 2013 roku. W tym etapie badań wykorzystałam metodę indywidualnych przypadków, techniką był wywiad w postaci kwestionariusza wywiadu. Wywiady, które trwały od prawie jednej do ponad dwóch godzin, prowadziłam w domu rozmówców lub w miejscu ich pracy po zakończeniu zajęć. Były one najczęściej kontynuowane, nawet do ponad trzech godzin, zwłaszcza po wyłączeniu dyktafonu, i obejmowały również inne nieporuszone w wywia-

Projekt badawczy został zrealizowany przez autorkę artykułu w ramach pracy doktorskiej, napisanej pod kierunkiem naukowym dr hab. Agaty Cudowskiej, prof. UwB na Wydziale Pedagogiki i Psychologii Uniwersytetu w Białymstoku. 
dzie zagadnienia oraz problemy, z którymi na co dzień borykają się nauczyciele. Do analizy danych jakościowych zastosowałam koncepcję Matthew B. Milesa i A. Michaela Hubermana (200o), na którą składają się następujące działania: redukcja danych, reprezentowanie danych oraz wyprowadzanie i weryfikacja wniosków.

Większość nauczycielek, biorąc udział już w pierwszym etapie badań, nie wyrażała zgody na objęcie ich dalszymi badaniami. Przejawiało się to albo w bezpośrednim komunikacie zanotowanym w kwestionariuszu ankiety „nie wyrażam zgody”, „nie zgadzam się”, albo też poprzez niepodanie swojego numeru telefonu, co uniemożliwiło nawiązanie dalszego kontaktu. $\mathrm{Z}$ tego powodu badania jakościowe zostały przeprowadzone wśród sześciu nauczycielek preferujących twórcze orientacje życiowe. Połowę z nich stanowiły nauczycielki edukacji wczesnoszkolnej, a połowę wychowawczynie świetlicy. Taki dobór nauczycielek do drugiego etapu badań ma również uzasadnienie w uzyskanych wynikach w zakresie preferencji twórczych orientacji życiowych. Pomimo że wychowawczynie świetlic w pierwszym etapie badań reprezentowały nieco ponad jedną trzecią respondentów ( $34,82 \%$ badanych), to stanowiły one $46,87 \%$ nauczycielek o twórczych orientacjach życiowych.

Nauczycielki uczestniczące $\mathrm{w}$ drugim etapie badań posiadały wykształcenie wyższe magisterskie, uzupełnione kursami kwalifikacyjnymi lub studiami podyplomowymi. Ich staż pracy był bardzo zróżnicowany i wynosił od 5 do 30 lat. Większość z nich stanowiły osoby ze stopniem awansu zawodowego nauczyciela dyplomowanego, natomiast tylko dwie były nauczycielami kontraktowymi w trakcie stażu na nauczyciela mianowanego.

\section{Irytacja twórczych nauczycieli w świetle badań własnych}

Jedną z kwestii, która irytowała badane nauczycielki, były formy sprawdzianów i konkursów wiedzy, do których przystępowali uczniowie. Ich zdaniem testy, a także pytania zamknięte negatywnie wpływały na wzrost wiedzy i umiejętności uczniów, a także na rozwój ich twórczych możliwości, gdyż nie było w nich miejsca na uzasadnienie swojego stanowiska. „Szablonowe są. To są najczęściej pytania, które wymagają konkretnej wiedzy" [nauczycielka edukacji wczesnoszkolnej, 6 lat pracy]. „Dziecko nie ma możliwości wyrażenia opinii, własnych sądów na dany temat. Nie ma pytań otwartych w testach. Czuje się przez to ujęte w takie ramy, schematy, nigdzie nie ma jego, nie ma gdzie się wykazać. Nie może przekazać swojego sposobu myślenia, swoich uczuć, emocji. Musi za to odzwierciedlić jedną, dwie prawidłowe odpowiedzi. (...) Sama chęć otworzenia się i pokazania swojego punktu widzenia nie jest tak istotna, jak poprawna odpowiedź" [wychowawca świetlicy szkolnej, 
13 lat pracy]. Jej zdaniem takie formy powinny być stosowane dopiero wówczas, gdy rozwinięta jest twórczość, indywidualne myślenie oraz otwartość dziecka. Inna z badanych nauczycielek [wychowawca świetlicy szkolnej, 30 lat pracy] uważała, że w konkursach wiadomości z różnego zakresu dziecko może się „wykazać tylko wiedzą z danego przedmiotu, natomiast twórczością nie". Formy te były bardzo schematyczne i nie pozwalały uczniom na wykazanie ich sposobu myślenia. Jako przykład przytoczyła rozmowę z uczniem, który brał udział w konkursie z zakresu informatyki i matematyki. „Zrobił uczeń tak, doszedł do wyniku bardzo dobrze. Wynik był ten sam co u wszystkich, ale jemu nie zaliczono zadania, bo doszedł do tego wyniku inną drogą". Schematy, które były obecne w szkole, utrudniały funkcjonowanie uczniów, którzy wybierali niestandardowe rozwiązania. „Dziecko ma coś na myśli, skoro wybiera taką, a nie inną drogę. I dzięki temu możemy później usłyszeć o takim czy innym nowym odkryciu, bo właśnie nie wszyscy idą tą drogą". Uczeń powinien mieć możliwość uzasadnienia swojego rozwiązania, gdyż „wtedy widać, czy myśli, czy nie, czy ściąga, czy w jakiś sposób nie nauczył się schematu", z którego nic nie rozumie. Forma konkursów, różnego rodzaju, irytowała także najmłodszą stażem nauczycielkę, która uczestniczyła w drugim etapie prowadzonych badań [wychowawca świetlicy szkolnej, 5 lat pracy]. W jej opinii powinny one przybierać raczej formę przeglądów, podczas których prezentowane są umiejętności uczniów z różnych obszarów. Dotyczyło to zwłaszcza konkursów artystycznych. „Wydaje mi się, że bardzo trudno jest ocenić umiejętności plastyczne. Widzimy, co jest narysowane, na jakim poziomie, natomiast nie jesteśmy w stanie określić ani intencji tego dziecka, ani jego możliwości. Być może ta praca jest naprawdę na miarę jego możliwości i powinna być nagrodzona tak od razu. Czy też [konkursy] poetyckie, dzieci wiersze piszą, opowiadania. Dla nich to jest po prostu coś niesamowitego. To jest ich wytwór, a inni już tak nie oceniają".

Badane nauczycielki były przekonane, że stosowane formy sprawdzania postępów uczniów wynikały przede wszystkim z łatwości weryfikacji ich poprawności, zarówno pod względem merytorycznym, jak i czasowym. Pytania otwarte, umożliwiające pokazanie uczniom swoich możliwości, powodowały, że „sami nauczyciele nie potrafili tego otwarcie ocenić” [wychowawca świetlicy szkolnej, 13 lat pracy] lub też „nauczyciele (organizatorzy) mieli później problem z interpretacją tej odpowiedzi" [nauczycielka edukacji wczesnoszkolnej, 6 lat pracy].

Twórczy stosunek nauczyciela do wykonywanej przez siebie profesji to „samokształcenie, podwyższanie swych kwalifikacji, doskonalenie własnego warsztatu" (Schulz, 1989, s. 79). Nauczyciele, z racji wykonywanego 
zawodu, zobowiązani są do stałego doskonalenia własnej wiedzy i umiejętności poprzez aktywny udział w różnych formach doskonalenia zawodowego organizowanego w ramach Wewnątrzszkolnego Doskonalenia Nauczycieli lub przez wyspecjalizowane placówki. Respondentki deklarowały, że uczestniczyły tylko w tych formach, które je interesowały. „Nie idę na kurs z powodu kursu, wybieram coś, co mi się przyda w pracy" [nauczyciel edukacji wczesnoszkolnej, 25 lat pracy]. „Wybieram kursy tylko i wyłącznie te, które mnie interesują. Nie interesuje mnie papier ani to, żeby mieć następny kurs. Tylko kursy, które mnie osobiście rozwijają, czyli dają jakąś dodatkową wiedzę" [wychowawca świetlicy szkolnej, 30 lat pracy]. Ich irytację wzbudzał jednak sposób przygotowania szkoleń dla nauczycieli. Krytykowały zarówno ofertę szkoleniową, jak również sposób ich prowadzenia. „Szkolenia organizowane przez $\mathrm{XXX}^{2}$, są typowo takie skostniałe, takie kostyczne, to są szkolenia, które nic mi więcej nie dają" [wychowawca świetlicy szkolnej, 30 lat pracy]. "Jako że XXX to, co oferuje, to jest po prostu... pozostawię to bez komentarza. Być może dla nauczycieli, którzy zaczynają dopiero pracę, to jest przydatne. Natomiast, jak się zapoznaję z tematyką tych kursów, to tak bez skromności powiem, że ja mogłabym prowadzić taki kurs..." [nauczycielka edukacji wczesnoszkolnej, 25 lat pracy].

Jedna z nauczycielek poruszyła także kwestię kosztów interesujących ją warsztatów: „Ja bym się zapisała na coś, ale takiego, co by mnie interesowało. A to, co mnie interesuje, to trochę kosztuje" [nauczyciel edukacji wczesnoszkolnej*, 25 lat pracy] $]^{3}$. W związku z tym uczestniczyła zazwyczaj w kursach organizowanych przez wydawnictwa, które nie spełniały jej oczekiwań. Proponowane białostockim nauczycielom formy doskonalenia zawodowego wzbudzały również ich irytację z powodu obsady kadrowej. Kursy były „prowadzone przez te same osoby, które skupiały się wokół tych samych tematów” [wychowawca świetlicy szkolnej, 5 lat pracy], a w związku z tym nie odpowiadały na potrzeby odbiorców. W efekcie nauczycielki, kończąc nawet studia podyplomowe czy kursy kwalifikacyjne, dotyczące pracy z uczniami o specjalnych potrzebach edukacyjnych, bardziej pracowały na „wyczucie, niż na podstawie wiedzy zdobytej podczas kursu" [nauczycielka edukacji wczesnoszkolnej $^{*}, 25$ lat pracy].

Ze względu na ochronę danych nazwy instytucji wskazanych przez nauczycielki na potrzeby niniejszego artykułu zostają zmienione na XXX.

3 W związku z tym, że w drugim etapie badań uczestniczyły dwie nauczycielki edukacji wczesnoszkolnej z dwudziestopięcioletnim stażem pracy, dla odróżnienia wypowiedzi jednej z nich oznaczyłam symbolem *. 
Kolejną kwestią, która wzbudzała irytację badanych nauczycielek, była biurokracja i duża liczba dokumentów, które musiały przygotowywać. Pochłaniało to czas, który mogłyby poświęcić na pracę z uczniami czy też doskonalenie zawodowe. Wynikało to zarówno z wymagań dyrekcji konkretnych placówek, jak też z wytycznych Ministerstwa Edukacji Narodowej. „Dużo biurokracji, trzeba wszystko wykazać na papierze, ująć tak, jak dyrekcja by sobie życzyła, żeby było ujęte" [nauczyciel edukacji wczesnoszkolnej, 6 lat pracy]. Ich irytację wzbudzała także konieczność przygotowywania scenariuszy prowadzonych zajęć. „Praca z dziećmi czy młodzieżą nie powinna ograniczać się do sztywnym form. Żadnych scenariuszy!!! Ogólny zarys, co chcemy poruszyć, co chcemy robić i do czego chcemy dojść, jaki ma być efekt... Nauczyciel twórczy nie powinien zamykać się tylko w sztywne ramy (...), że to musi zrealizować" [wychowawca świetlicy szkolnej, 30 lat pracy]. Zamiast tego proponowała obserwację dzieci, nawiązywanie z nimi kontaktu oraz dostosowywanie prowadzonych zajęć do aktualnych potrzeb uczniów.

Nauczycielki chętnie podejmowałyby więcej inicjatyw wspierających rozwój uczniów, ale wymagania ministerialne powodowały, że było to utrudnione, a czasami wręcz niemożliwe. Jedna z nich przyznała, że twórczy nauczyciel musi czasami przymknąć oko na wymagania formalne i działać według własnego pomysłu. „Żeby ten nauczyciel nie trzymał się tak bardzo tych ram, czasami trzeba też przymrużyć oko na to, co minister każe. To znaczy nie w tym, że tak powiem, kręgosłupie całym, ale w tych pobocznych nerwach" [nauczyciel edukacji wczesnoszkolnej, 25 lat pracy]. Czy więc chodzi o to, że kreatywność nauczyciela ma przejawiać się także w nierespektowaniu prawa oświatowego? Nauczycielkę edukacji wczesnoszkolnej [25 lat pracy] irytowały również systematycznie obniżane wymagania zawarte w podstawie programowej „Ten program jest taki okaleczony. Coraz mniej prac dłuższych się pisze. W tej chwili to tylko są zdania w drugiej klasie, a w II klasie to się już przecież pisało naprawdę długie prace, a w III to już wypracowania wręcz".

U najmłodszej stażem nauczycielki edukacji wczesnoszkolnej [6 lat pracy] irytację wywoływali także rodzice dzieci, którzy zapisywali je na zbyt dużą liczbę zajęć dodatkowych. Liczyli, że dzięki temu „one będą wspaniale rozwinięte. Natomiast okazuje się, że dzieci są zmęczone, znudzone, że (...) tego jest za dużo”. Apelowała, „żeby nie przesadzać z ilością zajęć, bo dziecko nie skupia się wtedy na niczym". Złościło ją także przygotowanie sal lekcyjnych do zajęć. „Często jeszcze są lekcje w sali, która salą jest tylko z nazwy, bo nie jest z funkcjonalności, i dzieciaki siedzą stłoczone. Sam nauczyciel też ma problem, żeby coś sensownego zrobić. Aczkolwiek mamy sprzęt multimedialny, 


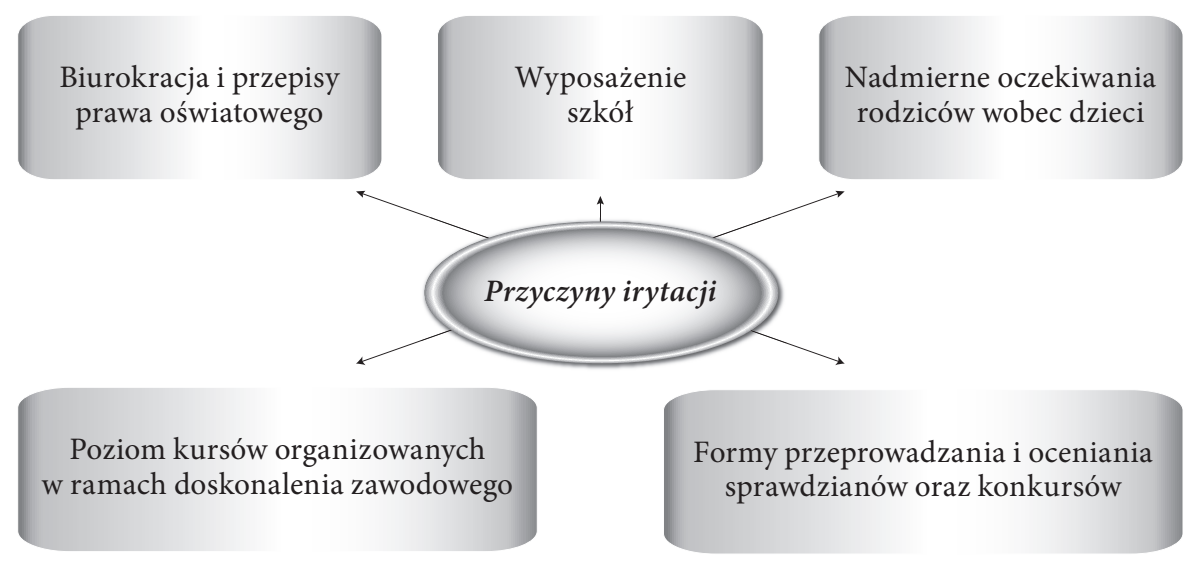

Sieć 1. Przyczyny irytacji nauczycielek preferujących twórcze orientacje życiowe

Źródło: badania własne

mamy tablice, projektory, wiec trochę się zmienia i część rzeczy można inaczej poprowadzić. Ale na pewno te warunki lokalowe są fatalne”. Analizując lata swojej pracy przyznała, że zmierza „w dobrym kierunku, aczkolwiek też mam czasami takie momenty, że zastanawiam się nad sensem tego co robię, zwłaszcza w perspektywie arkusza organizacyjnego i września”.

Redukcja danych zgromadzonych w badaniach umożliwiła syntetyczne przedstawienie przyczyn irytacji badanych nauczycielek, wykazujących twórcze orientacje życiowe (Sieć 1).

\section{Wnioski końcowe}

W wyniku przeprowadzonych wywiadów można stwierdzić, że praca sprawiała satysfakcję badanym nauczycielkom. Zdarzały się sytuacje, które wzbudzały ich irytację, jednak nauczycielki potrafiły sobie z nią poradzić i nie wywoływała ona ich zmęczenia czy też syndromu wypalenia zawodowego. Większość z badanych posiadała liczne plany zawodowe, które w dużej mierze dotyczyły doskonalenia zawodowego. Jednak w przypadku nauczycielki edukacji wczesnoszkolnej [ 25 lat pracy ${ }^{\star}$ ] sytuacja była niepokojąca. Jej wypowiedzi mogły świadczyć o objawach rezygnacji i zmęczenia. Sukces zawodowy utożsamiała $z$ latami pracy: „25 lat pracy... to, że wytrzymałam i nawet czasami jeszcze jest chęć". Natomiast jej plany zawodowe dotyczyły dotrwania do emerytury. W międzyczasie chciała „też trochę odpocząć, gdyż po 25 latach to się jednak człowiek też trochę wypala, niestety. W pewnym 
momencie już nie ma aż takiego zaangażowania, jak przez poprzednie lata było. Jeszcze teraz mam fajną klasę, ale jakby mi się gorsza klasa trafiła to nie wiem, czy ja bym miała siły. Myślę, że dobrze byłoby kiedyś iść na ten urlop zdrowotny, ale w którym momencie, to człowiek nie wie". Jej przypadek sugerował wystąpienie zmęczenia pracą, będącego efektem wysokich osiągnięć. Dotyczy ono osób, które zaczynają pracę pełne dobrych zamiarów, bardzo się angażują i stawiają wysoko poprzeczkę. „Dają z siebie wszystko i jeszcze więcej” (Pines, 2000, s. 37), a w momencie, kiedy nie da się już więcej, czują, że zawiedli i siebie, i innych.

W świetle przeprowadzonych badań irytację nauczycielek preferujących twórcze orientacje życiowe wywoływały różne aspekty szkolnej rzeczywistości. Do jej przyczyn zaliczyły one poziom kursów organizowanych w ramach doskonalenia zawodowego, formy przeprowadzania i oceniania sprawdzianów oraz konkursów, biurokrację, przepisy prawa oświatowego, nadmierne oczekiwania rodziców wobec dzieci, jak też wyposażenie szkół. Były to jednocześnie czynniki zaliczane do szkolnych inhibitorów twórczości (Szmidt, 2007). W związku z tym można stwierdzić, że badane nauczycielki irytowały te elementy, które utrudniały im realizowanie postulatu wychowania do twórczości. Rozwijanie twórczych postaw i zdolności dzieci stanowi szansę tworzenia ich własnego, niepowtarzalnego świata przeżyć oraz pozwala na przekroczenie granic wyznaczonych przez postawę konsumpcyjną, charakterystyczną dla współczesnego człowieka. Postawa konsumpcyjna ogranicza działanie do powtarzania schematów i oczekiwań, natomiast dzięki twórczości, człowiek może podążać ku temu co nowe i nieznane, podejmować aktywność, która jest wartością samą w sobie oraz środkiem do osiągnięcia innych celów (Biegajło, 2000).

\section{BIBLIOGR AFIA}

Biegajło M. (200o). Wychowanie do twórczości. Psychologia Wychowawcza, nr 1, s. 26-35.

Cudowska A. (2004). Kształtowanie twórczych orientacji życiowych w procesie edukacji. Białystok: Trans Humana.

Cudowska, A. (2014). Twórcze orientacje życiowe w dialogu edukacyjnym. Studium teoretyczno-empiryczne. Białystok: Wydawnictwo Uniwersyteckie Trans Humana.

Dubisz, S. (red.) (2003). Uniwersalny słownik języka polskiego (t. 1). Warszawa: Wydawnictwo Naukowe PWN.

Gulińska-Grzeluszka, D. (2010). Kompetencje nauczyciela przedszkola. W: E. Przygońska (red.), Nauczyciel. Rozwój zawodowy i kompetencje. Toruń: Wydawnictwo Adam Marszałek.

Grzegorzewska, M. K. (2008). Wpływ zmian wynikających z reformy oświaty na poziom stresu w grupie zawodowej nauczycieli. W: B. Muchacka, M. Szymański (red.), Nauczyciel w świecie współczesnym. Kraków: Oficyna Wydawnicza „Impuls”. 
Karwowski, M. (2010). Twórcza (?) osobowość nauczyciela: pedeutologiczne postulaty a uczniowskie preferencje. W: M. Karwowski, A. Gajda (red.), Kreatywność (nie)tylko w klasie szkolnej. Warszawa: Wydawnictwo Akademii Pedagogiki Specjalnej.

Kirenko, J., Zubrzycka-Maciąg T. (2011). Współczesny nauczyciel. Studium wypalenia zawodowego. Lublin: Wydawnictwo Uniwersytetu Marii Curie-Skłodowskiej.

Kwiatkowski, S. M. (2008), Oczekiwania społeczne wobec nauczycieli - w kierunku szlachetnej utopii. W: B. Muchacka, M. Szymański (red.), Nauczyciel w świecie współczesnym. Kraków: Oficyna Wydawnicza „Impuls”.

Miles, M. B., Huberman, A. M. (200o). Analiza danych jakościowych. Przekł. S. Zabielski, Białystok: Trans Humana.

Pines, A. M. (200o). Wypalenie - w perspektywie egzystencjalnej. Przekł. J. Radzicki, M. Żywicki. W: H. Sęk (red.), Wypalenie zawodowe. Przyczyny - mechanizmy - zapobieganie. Warszawa: Wydawnictwo Naukowe PWN.

Schulz, R. (1989). Nauczyciel jako innowator. Warszawa: Wydawnictwa Szkolne i Pedagogiczne.

Schulz, R. (1990). Twórczość. Społeczne aspekty zjawiska. Warszawa: Państwowe Wydawnictwo Naukowe.

Szmidt, K. J. (2007). Pedagogika twórczości. Gdańsk: Gdańskie Wydawnictwo Pedagogiczne.

Woźniak-Krakowian, A. (2013). Syndrom wypalenia zawodowego nauczycieli. Pedagogika. Prace Naukowe Akademii im. Jana Długosza w Częstochowie, t. 22, s. 119-131.

Zaborowski Z. (1986). Psychospołeczne problemy pracy nauczyciela. Warszawa: Wydawnictwa Szkolne i Pedagogiczne.

Znańska-Kozłowska, K. (2013). Wypalenie zawodowe - pojęcie, przyczyny i objawy. Zeszyty Naukowe Wyższej Szkoły HUMANITAS. Zarządzanie, z. 1, s. 105-113.

Żmigrodzki, P. i in. (2016). [hasło: Irytacja]. Wielki słownik języka polskiego. Pozyskano z: http://www.wsjp.pl/index.php?id_hasla=40890, [data dostępu: 5.10.2016].

\section{SUMMARY}

\section{What irritates creative teachers?}

There are numerous situations that cause irritation among teachers. The term irritation is also present in the context of a job burnout syndrome. The author took up this topic due to the consequences it brings both in professional and private life of the teachers. The article presents the results of the qualitative research, which was conducted in April and May 2013 by the author, within the framework of her doctoral dissertation. In this research participated teachers displaying preferences in the field of creative life orientations-people treating change and difference as a natural order of things; willing to take up new tasks; looking for new opportunities and ways to solve difficult situations. The author used a method of individual cases and a technique of an interview in the form of a questionnaire. The concept of qualitative data analysis by Matthew B. Miles and A. Michael Huberman has been used. In the light of the research, irritation of creative teachers was caused by such aspects of school reality as: the level of courses organised in the framework of vocational training, forms of organisation and evaluation of tests and competitions, bureaucracy, educational law, excessive expectations of parents towards their children, as well as the equipment of schools. In case of one teacher, work fatigue and discouragement has been noticed that could lead to the symptoms of a job burnout. The results of the research proved that these elements irritated the examined teachers that hindered the implementation of the postulate of education towards creativity KEY WORDS: creative teacher, irritation, job burnout. 